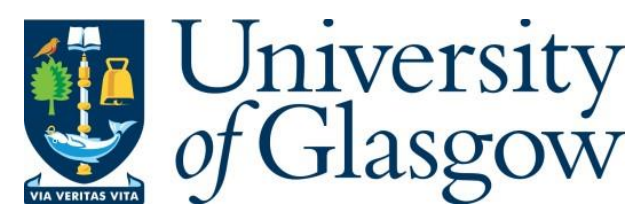

Hammill, F. (2016) Noël Coward, Rebecca West, and the modernist scene. Modernist Cultures, 11(3), pp. 351-369.

There may be differences between this version and the published version. You are advised to consult the publisher's version if you wish to cite from it.

$\underline{\text { http://eprints.gla.ac.uk/148126/ }}$

Deposited on: 15 September 2017

Enlighten - Research publications by members of the University of Glasgow http://eprints.gla.ac.uk 


\title{
Noël Coward, Rebecca West, and the Modernist Scene
}

\section{Faye Hammill}

\begin{abstract}
:
Coward and West shared a long friendship, and often met each other at theatrical openings, on transatlantic liners, and at parties hosted by the 'international set'. Their wary negotiation with one another's celebrity and cultural value played out not only at these social events but also in print, through reviews, gossip columns, and memoirs. Using the relationship between Coward and West as a case study, this essay explores the social scene of modernism, with attention to the suggestion of theatricality in the word 'scene'. It takes up the notion of the 'modernist party' as, on the one hand, a kind of stage on which celebrities from different spheres performed together, and, on the other, a happening which, through reports in print, contributed to the forming of literary reputations and to the public fascination with modern style.
\end{abstract}

Keywords: modernist party, performance, print culture, ocean liner, hostess

I knew him for over 50 years, not always easily. Our paths had followed different lines and though we often pleased each other we often irritated each other. I am so glad, in spite of this, that this interesting, amusing upright man never excluded me from his world. Last year he asked me to go with him to the première of 'Dear Winston'. I could not go; but when I recall the invitation it is as if I felt again the grasp of his hand, which was always just the right temperature, cool enough, warm enough, and expressed a unique kind of affection; dry but not dry like a desert, dry like a very good dry sherry. 
In this last document of their relationship, an image of hospitality brings Rebecca West and Noël Coward together. The image is also one of sophistication - the very good dry sherry signals not only sociability, but also taste and discrimination. These are qualities, West implies, that she and Coward shared, and that enabled them to move with ease in an elite social atmosphere. Yet the text of the obituary also foregrounds divergence and separation. In spite of their overlapping professional and social circles, West locates Coward in a different world from herself - one that she is happy to gain entrance to, but where she does not fully belong. Aligning him with popular entertainment, she writes about his preference for light music over 'good music', about his wit and panache, and about the grand show-business parties given in his honour. But she does not describe his artistic achievements. Costume and disguise are invoked several times; for instance, West comments: 'The public image of himself in top-hat and tails, the immortal spirit of the charming 'Twenties, was merely one of his many admirable inventions'. In spite of her admiration, West's reiterated trope of disguise seems to reinforce the association of Coward with performance and showmanship, and to distance him from her own literary and intellectual milieu.

West and Coward's improbable friendship was the product of a transatlantic social and cultural scene which connected intellectuals and modernist artists with popular performers, publishers, and journalists. Both were very high-profile figures. Coward's accessible plays and songs were familiar to enormous audiences, and he received extensive coverage in the news media as well as in the smart magazines. When West appeared on the cover of Time in 1947, she was described as 'indisputably the world's No. 1 woman writer'. ${ }^{2}$ Her glamour, her colourful private life, and her political outspokenness meant that her name was recognised by many who had not read her books, some of which were challenging texts that did not appeal to a mass audience. In the early phases of Coward's career, West was able 
to draw attention to him, beginning in 1920 when she favourably reviewed his farce I'll Leave It To You for Time and Tide. Later, when he had become the better-known of the two, he confessed that he aspired to the type of fame that she represented, remarking in a 1959 letter: 'In private I suppose I am a tremendous celebrity snob, and by celebrity I don't mean Brigitte Bardot but people of achievement like Somerset Maugham or Rebecca West'. ${ }^{3}$ His choice of two writers to represent 'achievement' reveals an aspiration to be taken seriously in literary terms, and not just as an entertainer.

As a case study, the relationship between West and Coward raises questions about celebrity culture and its anxious negotiation with serious literary culture, as well as about the way that reputations, and hierarchies of artistic value, were constructed through social and print-based networks. Both Coward and West had access to the 'international set,' a loose grouping of prominent figures who met in fashionable locations such as the French Riviera and on transatlantic liners. Both were regular guests of leading hostesses including Elsa Maxwell, Sybil Colefax, and Syrie Maugham, whose parties were, in turn, reported in numerous memoirs, sketches, diaries, and magazine items. These gossipy narratives were more widely read than most modernist literary texts, and in their references to avant-garde writers, artists, dancers, and musicians, as well as to visual culture (décor, fashions) they arguably generated new audiences for modernism as social performance. My concern in this essay is with the mediation of relationships, both on the level of introductions at parties, and on the level of written reports about them.

The early twentieth-century party was a key site for the display of modern style as well as for the forging of reputations and networks. The party can be modelled as, on the one hand, a kind of stage, and on the other, a print event. In the insightful introduction to her collection The Modernist Party (2013), Kate McLoughlin lists the types of gathering common in the era: 'from tea-parties to cocktail-parties, from lunch- and dinner-parties to 
extended house-parties', and so on. She comments: 'In these varying modernist parties, the twin propensities to constructive enlightenment and destructive excess [...] assume special resonance', given an historical context that included both the First World War and the rise of public relations and modern celebrity culture. ${ }^{4}$ The label 'modernist party' does give pause. In the volume as a whole, McLoughlin and her contributors concentrate primarily on the parties represented in texts by Joyce, Proust, Eliot, Mansfield and so on. These are parties imagined by, rather than attended by, modernists. The parties actually attended by the figures who now form the modernist canon were rarely exclusive gatherings of experimental artists and writers. Usually, they involved guests from a range of professional and cultural spheres; often, they included high society figures or stage and screen stars. The parties thus epitomise both modernism's elitism and its engagement with celebrity culture. They also counterbalance the traditional narrative of modernist isolation and social alienation. There is much scope, then, for further analysis of the promiscuously mixed and self-mythologising social scene of what we now call the modernist era.

\section{Modernist / Mixture}

Rebecca West's major contribution to modernist literature has now been acknowledged by critics, and she is usually identified as a writer affiliated to (if not always fully aligned with) modernist aesthetics and preoccupations. ${ }^{5}$ Debra Rae Cohen comments that critics have variously categorised West as 'Vorticist, socialist, feminist, modernist, Manichean, sentimentalist, essentialist, anti-communist - even [...] proto-postmodernist', all labels which are only appropriate to certain of her works, or certain passages within them. 'Such criticism', argues Cohen, 'duplicates rather than illuminates West's paradoxical positioning with regard to "modernist" and political groupings, in which temporary identification was often only mobilised as a mode of critique'. ${ }^{6}$ Yet it is clear, amidst all this debate, that West has 
something to do with the experimentation, renovation, difficulty, and outrageousness that are associated with modernism in the arts. Such claims are only rarely made on behalf of Noël Coward, and are not generally persuasive. It is true that Robert Graves and Alan Hodge offered a compelling - and concise - assertion of Coward's modernism in The Long WeekEnd (1940): 'Coward was the dramatist of disillusion, as Eliot was its tragic poet, Aldous Huxley its novelist, and James Joyce its prose epic-writer. They all had in common a sense of the unreality of time..$^{7}$ But this is not representative of Coward's reception in the early to midtwentieth century. A more typical evaluation is that of the American poet Robert Duncan, writing around 1960: 'Eliot represented a high sophistication, as Noel Coward represented a low sophistication for those who were not serious-minded. ${ }^{8}$ More recently, one or two critics have claimed Coward as a modernist on the basis of the somewhat simplistic argument that he engaged with contemporary or risqué themes. ${ }^{9}$ He himself was sceptical about the whole notion of the 'modern', writing in a 1926 article in Theatre Magazine that he considered the word hackneyed, but was forced to discuss it because 'I, according to my critics, am not only modern in my ideas but slightly decadent also'. In his own view, however, 'every age has its moderns', and 'the decadence of 1926 is no worse than the decadence of a century ago, only it is given more publicity'. ${ }^{10}$ In formal and stylistic terms, much of his work is fairly conventional, and none of it exhibits an avant-garde sensibility. Certainly, his revues and dramatic spectacles have innovative aspects, and it is possible to find parallels with modernist performance pieces. For instance, as I have argued elsewhere, his decades-long feud with Edith Sitwell can be partially explained by a certain competitiveness between them, arising from similarities in their techniques for creating musical entertainments. But this does not prove that Coward was a modernist; rather, it shows that he and Sitwell drew on the same popular cultural sources, such as music-hall and operetta. ${ }^{11}$ More broadly, it shows, as 
Rebecca D'Monte notes, that: 'The elastic, hybrid genre of the revue absorbed avant-garde influences from the Continent. ${ }^{12}$

In fact, it is not necessary to reposition Coward as a modernist in order to explore the relationship he had - and the challenge he posed - to the modernist scene. He engaged on both a textual and a social level with experimental artists and their works. He was able to translate aspects of modernism into popular idioms with great success, a success which itself inspired distrust in avant-garde circles. His mocking responses, such as the parodies of free verse in Chelsea Buns (1925) or his send-up of the Sitwells in the 'Swiss Family Whittlebot' sketch in London Calling! (1923), offer a kind of perverse adaptation of modernist technique. In his fiction, by contrast, he included respectful (though occasionally baffled) references to the novels of Virginia Woolf, Rosamond Lehmann, and Elizabeth Bowen; in his journalism, he praised radical dramatists from Shaw to Pinter; his letters record his reading of Proust's complete works; and he was personally acquainted with Max Beerbohm, Vita SackvilleWest, T.S. Eliot, and Osbert Sitwell, amongst others. His most sustained literary relationship, though, was with Rebecca West.

West and Coward both moved between literary and theatrical worlds. Although West's early stage career was brief, she maintained a strong interest in theatre. Her published writing includes fiction, journalism, and critical essays. Coward was an actor from childhood, and began writing in early adulthood. He published in the genres of drama, fiction, poetry, and journalism. Since their literary styles were so very different, it is unsurprising that their responses to one another's work were ambivalent. West admired Coward's dramatic strategies - in 1920 she said of I'll Leave It To You: 'It is delightful that a young man should be able to draw character like that; and even more delightful that he should want to do so. ${ }^{13}$ Her later comment in The Strange Necessity (1928) again describes Coward's work using a lexicon of lightness: 
Even the entertaining effect of Mr Noel Coward's comedies, though verbal wit contributes to it greatly, is very largely dependent on the amusing and entirely characteristic cadence of his sentences, which suggest that if one takes up almost any situation which the world pretends is sacred and solemn and of precious substance and examines it calmly, one will find that it can be snapped across and crumbled between the fingers like a biscuit. ${ }^{14}$

Coward, in evaluating West's work, was more vigorous both in his praise and in his criticism. He wrote in his diary in 1956 that he had just finished her novel The Fountain Overflows, describing it as 'a beautiful book, wise and compassionate, and peopled with curious, believable and most enduring characters'. He added that it is 'based on a standard of values, both moral and musical, that is impeccable'. ${ }^{15}$ Coward affirmed their shared values in relation to music, but West's obituary suggests she came to feel that her own tastes were on a higher plane. In terms of literary preferences, their differences became greater over time. Coward's enthusiasm for West's own fiction gradually faltered. In 1966 he recorded that he was 'struggling valiantly' with The Birds Fall Down, explaining:

Rebecca, in this book, is self-indulgent and verbose. [...] To weave intricate patterns with words may be fascinating for the writer, but $[\ldots]$ become[s] a pain in the arse for the simple reader. [...] Here am I thrashing around in a jungle of spies and Orient Expresses and lovely 'turn of the century' intrigues, all the ingredients I like best, and instead of being thrilled and riveted I am merely frustrated. ${ }^{16}$ 
A suspicion of obscurity and difficulty was always characteristic of Coward's commentary on contemporary literature, and as West became more 'modernist' he became less willing to engage with her work. Nevertheless, he still admired the intellectual quality of her conversation: during her stay with him in 1962 , he described her as 'a sweet house guest, gay and considerate and, oh, how gloriously intelligent'. Coward's shifting response to West's writing, as well as his growing friendship with her, is tracked in a total of twelve entries in his diary, which record a series of lunches, dinners, theatre visits, and 'heart-to-heart' talks, as well as Coward's pleasure in the thought that 'we are such old friends'. ${ }^{17}$

Coward did not start keeping a diary until 1941, and it is more difficult to reconstruct the social interaction that he had with West in earlier decades. However, numerous sources confirm that they met at parties which might be described as 'mixed', bringing together intellectuals with popular entertainers, high society figures, and political elites. Published memoirs and diaries of this early twentieth-century scene extend the audience for the party-as-performance far beyond the small group of invited guests. Douglas Fairbanks Jnr, in his autobiography The Salad Days (1988), described a cocktail evening hosted by Coward in 1932 as like 'a page out of Vanity Fair or a Michael Arlen short story. The theatrical stars of the day mingled with Mayfair's playboys and girls, and the aristocracy with the plutocracy and politicians. Even a member of the Royal Family'. ${ }^{18}$ The reason the party resembles a print event is not just because of its extraordinary glamour and the interest it generated, but also because of its mix of celebrities from different realms, which is reminiscent of the celebrity photo-spreads and 'Hall of Fame' features in Vogue and Vanity Fair. Each Hall of Fame presented a set of photographs of individuals ranging from experimental artists to business leaders, with captions indicating their latest achievements. Aaron Jaffe, in Modernism and the Culture of Celebrity (2005), describes the feature as a 'gallery of mixed worthies knowingly juxtaposing the elite and the popular'. ${ }^{19}$ 
Coward's cocktail party was held in London, and so it was not in fact Vanity Fair but British Vogue and Tatler that wrote up the event. They emphasised its quality of spectacle: Tatler commented on the 'decorative people' present, and the fact that Coward had 'decorated his studio very cleverly', while Vogue described 'a party in the enlightened tradition, all very white and witty'..$^{20}$ This phrase is doubly suggestive of theatricality. First, it implies that the conversational style at Coward's party is allied to the witty dialogue of his plays. Second, it evokes the fashion for white in the interior decor of the period. Coward had engaged Syrie Maugham, who was famous for her designs in white, to decorate his London apartment, and a similar décor was used for the stage sets for some of his plays. It is possible here to find parallels with modernist visual and stage art. According to John Potvin in Bachelors of a Different Sort: Queer Aesthetics, Material Culture and the Modern Interior in Britain (2014), Coward, created 'the home as a stage for modernism', and in her decorating scheme, 'Maugham appropriated the purity of non-colour to lend a sense of modernist glamour'. ${ }^{21}$ The notion of modernist glamour is also explored by Judith Brown in Glamour in Six Dimensions: Modernism and the Radiance of Form. Describing the use of cellophane in the stage set and costumes for Virgil Thomson and Gertrude Stein's Four Saints in Three Acts (1934), Brown comments that 'blankness, absence and transparency' had an important impact 'on the modern stage, and on the modern subject'. ${ }^{22}$ In Coward's case, though, I would suggest that the label 'moderne' would be more appropriate than 'modernist'. This term is generally used in the context of design history: as Steven Heller and Louise Fili explain, 'In the 1920s, when the industrialized world entered a machine age, an elegant, streamlined style known as art moderne was adopted by designers in Europe, North America and Asia and applied to architecture, furniture, jewelry, clothing' and so on. ${ }^{23}$ The word 'moderne' suggests a slick, elegant style rather than one that was challenging, provocative, or disorientating in the manner of avant-garde visual and stage art. 
The 'moderne' style, and the fashion for white, were used to particular effect in Design for Living, a play set in the contemporary moment. It premiered in New York in 1933 but was not produced in London for another six years, due to the more rigorous British system of theatre censorship. ${ }^{24}$ In his biography of Coward, Philip Hoare says of Design for Living: 'The world of the play is the international beau monde, a transatlantic high society dressed by Molyneux and furnished by Syrie Maugham'. ${ }^{25}$ Maugham was recognised for her glamorous projection of the self, and she was one of London's leading hostesses. ${ }^{26} \mathrm{Her}$ parties, according to cultural historian Sue Shephard, brought together a 'splendid list of young lions, mostly theatre people, café aristocracy, editors of fashion magazines, writers and artists such as Arnold Bennett, Cecil Beaton, 'Cocky' Cochran, Noël Coward, Rex Whistler, Oliver Hill, Rebecca West and the Prince of Wales'. ${ }^{27}$ This set of names offers a nice sample of the heterogeneous London party scene. Traditionalists such as Bennett met modernists such as architect Oliver Hill, while a man from a lower middle-class suburban background (Coward) came into contact with royalty. 'Parties too were regarded as a form of theatre', comments Shephard, citing reports in Vogue about the bright lighting at Maugham's parties, which created the effect of a stage set. ${ }^{28}$ Indeed, the more spectacular the party, the more likely it was to attract reporters from magazines such as Tatler and Vogue. The party's status as event was crucial in generating novelty in the context of the repeating annual cycles of periodical time and of the social calendar.

Actual theatre was sometimes incorporated into parties, when hosts requested entertainment from guests who were actors or musicians. In the first volume of his autobiography, Present Indicative (1937), Coward notes that the New York hostess Frances Wellman 'administered, like Elsa Maxwell in Paris and Sybil Colefax in London, the best social mixtures. At the crack of her whip Park Avenue clapped Broadway on the back, and Broadway generously went through its hoops for Park Avenue'. ${ }^{29}$ Wellman has been written 
out of most histories of the early twentieth-century scene, but Maxwell has received some acknowledgement and Colefax is quite a prominent figure. These two, like Syrie Maugham, exerted an important influence through their roles as hostesses, particularly when they brought bohemian and high society into contact. Maxwell, an American, recalls in her (probably ghost-written) book, R.S.V.P.: Elsa Maxwell's Own Story (1954), that the first time she entertained a royal guest was when Princess Helena Victoria sat on the floor of her tiny London flat 'and had the time of her life laughing at the antics of four young music-hall troupers named Noel Coward, Bea Lillie, Gertrude Lawrence, and Ivor Novello'. ${ }^{30}$ Her autobiography contains several enthusiastic descriptions of both Coward and West, and she did not seem to resent Coward's satirical song 'I've been to a marvellous party', which was obviously about her. ${ }^{31}$ Maxwell was not wealthy and is not widely recognised as a patron of modernism. Yet she entertained Diaghilev, Nijinsky, Serge Lifar, Fritz Kreisler, and many others associated with modernism in the performing arts, often introducing them to moneyed and powerful people who had an impact on their careers. In Paris in 1922, she opened a night club in partnership with Edward Molyneux (who would become a household name when he designed the dresses for Coward's Private Lives in 1930). The floorshow at the club featured Josephine Baker, that 'phenomenon of Modernism', as Anne Anlin Cheng describes her. ${ }^{32}$

While Maxwell hosted modernist musicians and performers, Lady Colefax preferred literary and intellectual guests, although she liked to bring them together with celebrities from other spheres. Her parties, like Maxwell's, had a strong element of theatre. Rebecca West, reminiscing late in life about the vanished 'concept of society and entertainment' which prevailed in her youth, described Colefax as 'one of the brilliant stage managers of this social setting'. ${ }^{33}$ In 1928, Colefax invited Virginia Woolf to lunch to meet Noël Coward, and Woolf then wrote to Vita Sackville-West: 'I fell in love with Noel Coward, and he's coming to tea'. ${ }^{34}$ Coward, too, seemed enamoured with Woolf and fervently praised Orlando, which appeared 
soon after their first meeting. ${ }^{35}$ In another 1928 letter, Woolf referred to Colefax and in the same breath to West, whom she had lately met at a party hosted by the highbrow Vogue editor Dorothy Todd:

I dont [sic] expect to feel wise when I'm talking to, shall we say, Sibyl Colefax or Rebecca West - who's a very nice woman, though. I met her the other day at a party $[\ldots]$ and was amused to find how awed one still is by celebrities, and then they turn out to be much like other people. ${ }^{36}$

Dramatising her own performance on the party scene, Woolf presents herself as anxious and uncertain. Yet in a later text, 'Am I a Snob?' (originally a talk presented to the Memoir Club in the mid-1930s), she recounts the development of her intimacy with Colefax in tones of irony: 'She would exclaim, "Oh how I long to be a writer!" And I would reply, "Oh Sibyl, if only I could be [a] great hostess like you!"'. Indeed, Woolf gradually came to find her friend's hospitality tiresome: 'What with Noel Coward on my left and Sir Arthur [Colefax] on my right, I felt I could no longer bring myself to dine with Sibyl' (190). ${ }^{37}$ As Rebecca Cameron notes, Woolf had admired Coward's work when she first met him, in 1928, but by 1934 she despised it. ${ }^{38}$ Between 1928 and 1934, then, Woolf had grown tired of both Colefax's and Coward's party tricks and was no longer in awe of their fame, but she retained a great respect for West's intellect, despite the awkwardness of their personal interactions. ${ }^{39}$ Coward, on the other hand, continued to admire Woolf, and wrote another fan letter to her in 1933, on the publication of Flush. ${ }^{40}$ His attitude to Woolf as well as West seemed to betoken his desire to be taken seriously as a writer, although it is noticeable that he expressed admiration only for their more accessible books. In this tangle of interactions among Coward, West, and Woolf, 
we see a certain shifting about of intellectual and social capital, which occurs in tandem with variations in each individual's sense of their own significance and reputation.

The narrative about Colefax in 'Am I a Snob?' culminates with her suggestion to Woolf that they plan 'fortnightly parties - now at Tavistock Square, now at Argyll House; we were to ask four of our friends; she was to ask four of hers; Bloomsbury and the great world were to mix'. ${ }^{41}$ This, Woolf thought, would never do. And yet such mixtures did frequently occur, without the need for elaborate planning. Recent research on literary networks explores the ways that economic, cultural, and social capital interacted through personal and professional links. In modernist studies, particular emphasis has been placed on the interdependence of social networks (organised around salons, country houses, and restaurants) and print networks (organised around periodicals, publishers, and bookshops). ${ }^{42}$ These studies demonstrate that the major modernists were linked to all sorts of diverse and unlikely figures from different classes and professional areas, so that their gatherings provide an emblem of the mixing of high and low, elite and popular, as well as a way of tracing patterns of influence and intellectual exchange.

\section{Brilliant / Boring}

McLoughlin argues that the party, and the performance anxiety it induces, took on a new intensity in the early twentieth century because:

The networks of communication are more efficient, ensuring that gossip can travel faster; in the era of high capitalism, competition is fiercer than ever. ... The party as performance, as display, as $d o$, becomes more than ever an 'exercise in public relations' in the modernist period, when that industry was invented. ${ }^{43}$ 
This element of display comes across particularly clearly in Confessions and Impressions (1930), a daring and rather scandalous memoir of the 1920s by the writer and magazine editor Ethel Mannin. She describes a party hosted by George Doran, who published an impressive range of authors including Virginia Woolf, John Dos Passos, Arthur Conan Doyle, and O. Henry. His publishing house, like his parties, was a site of encounter between modernist and popular literary cultures. Mannin writes

I shall always carry in my mind a picture of Noel Coward in George Doran's sitting-room at the Savoy one night after a party. 'The distinguished American publisher' had just made a remark about being 'ware of women with loose hips, because it generally went with loose lips. Noel leapt up and did a pas seul round the room, with his coat-tails flying, chanting like a revue catch-number:

'Loose about the hips,

Loose about the lips.'

He said what 'marvellous' words they would make for a fox-trot song or a revue number.

Rebecca West was there, vivid and vivacious as always. She is a brilliant mimic, but with her one can never feel quite comfortable; there is always the feeling that when one has left the room she will be as amusing about oneself. She radiates light like a diamond, but not warmth. ${ }^{44}$

In this account, Coward and West do not appear at all intimate: they seem only to brush against each other at a party, just as the paragraphs about them brush against each other in Mannin's text. Yet they are both performing - Coward dancing, and West doing impressions of absent members of their circle. Mannin implies that the effects of 'brilliance' that both 
produce may conceal a lack of sincerity or of serious achievement. By repeating the word 'revue', she firmly aligns Coward with popular culture, and she is also sceptical about the 'genius' (a word placed in inverted commas) which his friends attribute to him. ${ }^{45}$ She seems more respectful of West's intellect, yet even here, the word 'mimicry' suggests imitation rather than originality. This commentary is apparently about the social performances of West and Coward, but underlying it is a judgement of their value as artists.

Memoirists, of course, present rehearsed versions of the self, and represent their famous acquaintances in ways which are always in some sense strategic. In Present Indicative, Coward constructs an alternative narrative of his acquaintance with Mannin, remarking that he had only met her twice but that he had been 'flattered to discover, upon reading her book, Confessions and Impressions, recently, that these two brief encounters had obviously constituted, in her mind, a delightful intimacy'. ${ }^{46}$ It is possible that the part of her account which really annoyed Coward was her comment that she tended to 'bracket and compare Noel Coward and Beverley Nichols'. Coward and Nichols, a journalist and novelist, knew each other well, yet in his diary, Coward remarked that while Nichols was kind and amusing, he was also 'pink and summer puddingish and liable to be swayed by sawney sentimental values'. ${ }^{47}$ Coward himself was frequently accused of being sentimental, and yet wished to be considered intellectual, as is clear enough from his attempt to align himself with West and dissociate himself from Nichols. Reading these different texts alongside one another, the effect is of a constant jockeying for position, a process that started at the parties themselves, and continued in printed retrospects of them.

Several competing scales of value can be discerned in these records of social sparring, and especially in the ambiguous meanings of evaluative terms such as 'brilliant' and 'genius'. They recur in another narrative of an encounter between Coward and West, in a book by Sewell Stokes. Stokes was a gossip columnist who, as Margaret Stetz notes, 'first made his 
name through his friendships with famous women'. ${ }^{48}$ He published two volumes of sketches of celebrities, Personal Glimpses (1924) and Pilloried! (1928). The first includes sneering remarks on Coward's precocious cleverness, while the second briefly dismisses him as 'a brilliant manipulator and reviser of Edwardian comedies'. The word 'brilliant' is used by Stokes, as it was by Mannin, with an edge to it, to suggest glitter or shine rather than substance. Stokes seems keen to dismantle West's reputation for brilliance, describing her as living proof of 'my theory that one brilliant woman - brilliant in a professional sense - is never quite brilliant enough to praise another behind her back'. A whole chapter of Pilloried! is devoted to West, whose guest Stokes had been in Antibes. He comments sneeringly on her prominence in the print media. 'Is it in order that Rebecca West may follow the activities of her numerous friends that gossip pages are provided in the newspapers?', he wonders. He recalls a day in 1927 when he saw, in a sensational Nice newspaper, a notice of her arrival on the Riviera, and also read in 'that exclusive, that modish journal' (i.e. Vanity Fair) that West had been nominated to their Hall of Fame. ${ }^{49}$ The paragraph in Vanity Fair nominates West:

because she is politically one of the most active women in Europe, $[\ldots]$ because she has contributed support at once wise and intrepid to the cause of female suffrage in England; because, having gained an admirable reputation as a critic, she turned to fiction, and in The Judge achieved a unique distinction; [...] but chiefly because, for all the richness of her gifts, she remains young, beautiful, brilliant, genuine and feminine. ${ }^{150}$

This format, typical for the Halls of Fame, begins with achievements in public life but ultimately subordinates them to personal qualities. Vanity Fair often presented itself as the equivalent of a fashionable party - for example, a 1918 advertisement ran: 'Vanity Fair binds 
between the covers of a single magazine, the table-talk of a dinner party - at which cosmopolitan, well-bred, cultivated people discuss the news of their varied world'. ${ }^{51}$ Accordingly, the magazine judged celebrities as if they were potential guests, evaluating their charm before anything else.

Stokes both reinforces and counteracts Vanity Fair's account of West. He observes: 'She has a "presence", which must, had she continued her early stage career, have brought her to the front rank of that profession.' The word 'presence' evokes her compelling personality, which makes her a success on social occasions as well as on the stage. It also suggests her visibility: she is a prominent figure, with access to elite circles, but is herself inaccessible to many of those who would recognise her from media photographs. Stokes, though, evokes West's presence in terms of 'a ray of dazzling electric light or a breath of expensively scented air'. Here, his phrases are barbed, and suggestive of artificiality. To demonstrate the insincerity of West's social performance, he reports the mocking remarks she allegedly made while lunching with him:

'And Lady Diana Cooper', I ventured. 'You came over in the boat with her from New York. What was she really like?'

'Delightful! So was Noel Coward. We all came over together. But, you know, even Diana Cooper and Noel Coward became a little trying after a time. We all kept together - exclusively. Noel saw to that. I think it was a publicity stunt of his: being the centre of the 'smart set' on the boat. Other people on board used to watch us in our corner - enviously, suspiciously. Probably they thought we were being frightfully wicked and 'fast', when half the time we could think of nothing better than to play guessing games. 'Clups' was the most idiotic of these games. Frequently Noel, with a rapt expression on his face, would exclaim: 'Isn't Diana 
marvellous at "Clups"!' At moments like that I felt like the poor rich girl. I wanted to turn to our envious watchers and say: 'We're not having such a very lovely time after all!'.52

Stokes picks up on the significance of the ocean liner as a kind of stage, on which the parties held by celebrity passengers were observed by many spectators. Coward said of one of his crossings to New York, in 1925: 'The whole trip consisted of gatherings. We had bathing parties, cocktail parties, dinner parties and poker parties.' The liner was also a space of experimentation: a class-segregated site of leisured sociality, in which the rules of on-shore life were somewhat suspended. On this particular trip Coward, travelling with Basil Dean and Gladys Calthrop, met Mercedes de Acosta with Eva Le Gallienne who had lately shocked Paris audiences by performing naked in de Acosta's play Sandro Botticelli. Coward noticed their highbrow poses: 'they alternated between intellectual gloom and feverish gaiety and wore black, indiscriminately, for both moods'. ${ }^{53}$ Le Gallienne and Calthrop's shipboard meeting was thought to have turned into an affair. What Shawna Ross calls the 'intensified intimacy of a cruise ship' ${ }^{54}$ made liners ideal settings for plays, stories and musicals in this era - examples range from the experimental to the highly commercial, from Osbert and Sacheverell Sitwell's play All at Sea (1927) to Cole Porter's musical Anything Goes (1934), Anita Loos's Gentlemen Prefer Blondes (1925) and several of Evelyn Waugh's books. West and Coward themselves evoked the golden age of the ocean liner in texts they wrote later, during the age of air travel. ${ }^{55}$ In Pilloried!, Stokes certainly trades on this glamorous aspect of ocean travel and international celebrity, and it is likely that his book appealed to people who would never have read West or any other modernist writers. Yet his primary concern seems to be to subvert West's and Coward's reputed brilliance with a counter-image of idiocy and dullness. 
West, evidently feeling her friendship with Coward to be threatened by this malicious account, wrote to warn him about Pilloried!, in which:

I am made to refer to you with weary loathing as having been a terrible bore on a trip we made together on the Olympic. The fact is that I told him that I was certain that people had thought that Syrie Maugham, Diana Cooper and you and I and the rest of that group were all engaged in highly sophisticated practices probably of a distinctly vicious nature when we all went off together after dinner and that actually we played quite simple games. I did say that I thought Diana Cooper extremely socially gauche and tiresome but at no time did I express anything regarding you except the greatest admiration and liking. ${ }^{56}$

Apparently, West's main anxiety was about her alleged description of Coward as boring. To describe a guest or host as boring was the most damning of all possible judgements, since the pursuit of novelty was as important for high society as it was for modernist art. 'Are you a bore?' asked Vanity Fair in a 1926 advertisement for itself, adding: 'Most of us are [...] just beginning to be bores $[\ldots]$ We don't read - or know about - the new books; $[. .$.$] hear, or read$ about, the new operas; meet the new celebrities.' The result is: 'we are not invited to the most amusing house-parties, dinners or dances'. ${ }^{57}$ And yet, the continual circulation of the same group of people through the same cities, houses and ships did inevitably lead to boredom. Coward remarked, in a letter to Alexander Woollcott describing the atmosphere of London in May of 1939: 'Sybil Colefax is entertaining but not very'. ${ }^{58} \mathrm{He}$ also wrote of his early experience of New York society: 'It didn't take me long to realise that there was little or no novelty in any large party; people looked the same and talked the same and sang the same songs and made the same jokes. ${ }^{159}$ Even the structure of the sentence, with its repeating 
patterns, is designed to evoke boredom. Importantly, Coward's comment also emphasises the way that parties reinforced the group identity of an exclusive 'set', whose gatherings were visible, yet not at all accessible, to a wider public.

\section{Conclusion}

In biographies of Coward and West and in critical discussion of their work, little evidence can be found that they were even acquainted. Yet a search through the periodical archive as well as through diaries, memoirs, and critical essays reveals many threads linking them to one another, and to a shared professional and social network. Scholars have evidently not thought this a connection worth pursuing. ${ }^{60}$ It does not involve sex, scandal, or a feud. It does not indicate literary influence or collaboration. Nevertheless, the surviving record of their interaction is revealing in many ways. In particular, it illuminates the competing notions of 'value' that governed their shifting opinions of one another as well as their reputations among their peers. Although West's cultural capital was considerably greater than Coward's, the two were valued similarly in social terms - as brilliant, amusing, and glamorous party performers. This meant that they were given access to elite groups based on intellect, as well as to those based on wealth or breeding. A new hierarchy of cultural power emerges when we think in these terms. While modernist art tends to privilege the point of view of the outsider, the marginalised, and the rebellious, modernists themselves were often part of a glittering, fashionable, and highly publicised social scene. Written records of West's and Coward's presence at the same events reveal that they were part of an interconnected social world, in which encounters between modernists and film stars, writers and dancers, duchesses and journalists, were commonplace. Here, we have a counter-narrative to modernism's emphasis on isolation and introspection, but at the same time, this social scene can be understood as an element of the staging of modernism and modern style for a wider public. The parties of the 
era are therefore an ideal way to figure modernism: they were open only to coteries and reinforced the dominance of a small, densely networked elite, yet they formed a spectacle for contemporary readers of smart magazines and, in later decades, for readers of published diaries and memoirs. The more these events are recorded, mythologised, and accessed retrospectively, the more their 'coterie' effect emerges as itself a mediated effect of publicity.

\section{Acknowledgements}

Research for this article was funded by a British Academy Mid-Career Fellowship. Sincere thanks also go to David Goldie and Mark Hussey, as well as to the editors of this special issue, for very astute comments on draft versions of the essay. Many thanks also to Debra Rae Cohen and the International Rebecca West Society for the initial opportunity to discuss this topic.

\footnotetext{
Notes

${ }^{1}$ Rebecca West, 'Blithe spirit of a cool Coward', Sunday Telegraph, 1 April 1973, p. 20.

${ }^{2}$ Marina MacKay, Modernism and World War II (Cambridge: Cambridge University Press, 2007), p. 44.

${ }^{3}$ The Letters of Noël Coward, ed. by Barry Day (London: Methuen Drama, 2007), p. 651.

${ }^{4}$ Kate McLoughlin,'Introduction: A Welcome from the Host', in The Modernist Party, ed. by McLoughlin (Edinburgh: Edinburgh University Press, 2013), pp. 1-24 (p. 2).

${ }^{5}$ A foundational study is Bonnie Kime Scott's Refiguring Modernism: Postmodern Feminist Readings of Woolf, West, and Barnes (Bloomington: Indiana University Press, 1995). Among the articles on West and modernism, see in particular Laura Hefferman, 'Reading Modernism's Cultural Field: Rebecca West's The Strange Necessity and the Aesthetic "System of Relations"', Tulsa Studies in Women's Literature, 27 (2008), 309-25.

${ }^{6}$ Debra Rae Cohen, 'Rebecca West's Palimpsestic Praxis: Crafting the Intermodern Voice', in Intermodernism: Literary Culture in Interwar Britain, ed. by Kristin Bluemel (Edinburgh: Edinburgh University Press, pp. 150-67 (p. 150).

${ }^{7}$ Robert Graves and Alan Hodge, The Long-Weekend: A Social History of Great Britain, 1918-1935 (London: Hutchison, 1985), p. 147.

${ }^{8}$ Robert Duncan, The H.D. Book, ed. by Michael Boughn and Victor Coleman (Berkeley: University of California Press, 2011), p. 225. See also my discussion of Coward and sophistication in Sophistication: A Literary and Cultural History (Liverpool: Liverpool University Press), pp. 113-18.

${ }^{9}$ See for instance Penny Farfan, 'Noël Coward and Sexual Modernism: Private Lives as Queer Comedy', Modern Drama 48 (2005), pp. 677-88. John Potvin makes a similar claim (discussed below).

${ }^{10}$ Noël Coward, 'The Truth About Us Moderns', Theatre Magazine, n.d. [1926], p. 10. Birmingham, Cadbury Research Library, MS Noël Coward Collection, Section D Box 2, scrapbook '1925-28 USA'.

${ }^{11}$ Faye Hammill, 'Noël Coward and the Sitwells: enmity, celebrity, popularity', Journal of Modern Literature 39 (2015), in press.

${ }^{12}$ Rebecca D'Monté, British Theatre and Performance, 1900-1950 (London: Bloomsbury Methuen Drama, 2015), p. 63.
} 
${ }^{13}$ Rebecca West, 'The Theatre: I'll Leave it to You', Time and Tide 1 (30 July 1920), pp. 24647 (p. 247).

${ }^{14}$ Rebecca West, The Strange Necessity: Essays and Reviews (London: Virago, 1987), pp. 33-34. Compare Robert Scholes' notion of 'durable fluff', Paradoxy of Modernism (New Haven: Yale University Press, 2006), p. 144.

${ }^{15}$ The Noël Coward Diaries, ed. by Graham Payn and Sheridan Morley (London: Weidenfeld \& Nicolson, 1982), p. 341.

${ }^{16}$ Ibid., pp. 637-38.

${ }^{17}$ Ibid., p. 515, p. 265.

${ }^{18}$ Douglas Fairbanks Jnr, The Salad Days (London: Collins, 1988), p. 189.

${ }^{19}$ Aaron Jaffe, Modernism and the Culture of Celebrity (Cambridge: Cambridge University Press, 2005), p. 237. See also Faye Hammill, 'In Good Company: Modernism, Celebrity and Sophistication in Vanity Fair', in Modernist Star Maps, ed. by Aaron Jaffe and Jonathan Goldman (Farnham: Ashgate, 2010), pp. 123-36.

20 'The Letters of Eve', Tatler, 27 July 1932, p. 133; Vogue, qtd in Philip Hoare, Noël Coward: A Biography (University of Chicago Press, 1998), p. 157.

${ }^{21}$ John Potvin, Bachelors of a Different Sort: Queer Aesthetics, Material Culture and the Modern Interior in Britain (Manchester: Manchester University Press, 2014), p. 201, p. 226.

22 Judith Brown, Glamour in Six Dimensions: Modernism and the Radiance of Form (Ithaca: Cornell University Press, 2009), p. 157, p. 158.

${ }^{23}$ Steven Heller and Louise Fili, Dutch Moderne: Graphic Design from De Stijl to Deco (San Francisco: Chronicle Books, 1994), p. 6.

${ }^{24}$ On the differences between British and American censorship practices in the early 1930s, see Jenna Simpson, 'Reforming the Stage and Screen: How Expectations, Audiences, and Economics Shaped the Film and Theatre Censorship Movements in Early-1930s New York', Constructing the Past 7.1 (2006). <http://digitalcommons.iwu.edu/constructing/vol7/iss1/10> [accessed 14 October 2015]

${ }^{25}$ Hoare, p. 248.

${ }^{26}$ On Maugham, glamour, and theatricality, see Pauline C. Metcalf, Syrie Maugham: Staging Glamorous Interiors (New York: Acanthus Press, 2010).

${ }^{27}$ Sue Shephard, The Surprising Life of Constance Spry (London: Macmillan, 2010), p. 119.

${ }^{28}$ Shephard, p. 120.

${ }^{29}$ Noël Coward, Present Indicative (London: Heinemann, 1937), pp. 271-72.

${ }^{30}$ Elsa Maxwell, R.S.V.P.: Elsa Maxwell's Own Story (Boston: Little, Brown, 1954), p. 10. On ghostwriting, see Sam Staggs, Inventing Elsa Maxwell: How an Irrepressible Nobody Conquered High Society, Hollywood, the Press, and the World (New York: St Martin's Press, 2012), p. 9.

${ }^{31}$ See Coward's annotation in The Essential Noël Coward Songbook (London: Omnibus, 1980), p. 76.

${ }^{32}$ Anne Anlin Cheng, Second Skin: Josephine Baker and the Modern Surface (New York: Oxford University Press, 2011), p. 4.

${ }^{33}$ Letter to Michael Bloch, qtd in Kirsty McLeod, A Passion for Friendship: Sibyl Colefax and her Circle (London: Michael Joseph, 1991), p. 98.

${ }^{34}$ A Change of Perspective: The Letters of Virginia Woolf Volume III: 1923-1928, ed. by Nigel Nicolson and Joanne Trautmann. London: Hogarth, 1977, p. 471.

${ }^{35}$ Letters of Noël Coward, p. 151.

${ }^{36}$ Leave the Letters Till We're Dead: The Letters of Virginia Woolf Volume VI: 1936-1941, ed. by Nigel Nicolson and Joanne Trautmann. London: Chatto and Windus, 1983, p. 521. Woolf writes that the party was hosted by her sister Vanessa, but a footnote corrects this. 
${ }^{37}$ Virginia Woolf, 'Am I a Snob?', in Moments of Being: Unpublished Autobiographical Writings, ed. Jeanne Schulkind (London: Chatto and Windus, 1976), pp. 182-98 (p. 190). For discussion of this essay, see Sean Latham, Am I a Snob? Modernism and the Novel (Ithaca: Cornell UP, 2003), 1-2; 15-17. On Woolf and parties, see Bryony Randall, 'Virginia Woolf's Idea of a Party', in The Modernist Party, ed. by McLoughlin, pp. 95-111.

${ }^{38}$ Rebecca Cameron, "'Shrill small voices ... drowned out by the general trumpetings of praise": The Reception of Noël Coward's Cavalcade', The Space Between 9 (2013), 77-100 (p. 77).

${ }^{39}$ On Woolf and West, see MacKay; Douglas Mao, 'Rebecca West and the Origins of $A$ Room of One's Own', Modernist Cultures 9 (2014), 186-212; also Mark Hussey, 'Could I Sue a Dead Person?: Rebecca West and Virginia Woolf', in Virginia Woolf and her Female Contemporaries: Selected Papers from the 25 th Annual Conference on Virginia Woolf, ed. Julie Vandivere and Megan Hicks (Clemson: Clemson University Press), in press.

${ }^{40}$ Letters of Noël Coward, p. 152.

${ }^{41}$ Woolf, 'Am I a Snob?', p. 191.

${ }^{42}$ Exemplary studies include Peter Brooker, Bohemia in London: The Social Scene of Early Modernism (Basingstoke: Palgrave Macmillan, 2007); Jason Harding, The Criterion: Cultural Politics and Periodical Networks in Inter-War Britain (Oxford: Oxford University Press, 2002); and Leonard and Virginia Woolf, the Hogarth Press and the Networks of Modernism, ed. by Helen Southworth (Edinburgh: Edinburgh University Press, 2010). ${ }^{43}$ McLoughlin, pp. 5-6.

${ }^{44}$ Ethel Mannin, Confessions and Impressions (Harmondsworth: Penguin, 1937), pp. 124-25.

${ }^{45}$ Mannin, p. 123.

${ }^{46}$ Coward, Present Indicative, p. 115.

${ }^{47}$ Noël Coward Diaries, p. 637. On Nichols and Coward, and on Nichols' role as 'part of a network of literary influence and exchange that informed works now considered canonical', see Erica Brown, 'The Rise and Fall of "The Original Bright Young Thing": Beverley Nichols, Crazy Pavements (1927) and Popular Authorship', Review of English Studies 66 (2014), 144-63.

${ }^{48}$ Margaret D. Stetz, "'Sideways" Feminism: Rebecca West and the Saturday Evening Post, 1928', The Space Between 9 (2013), 61-75 (p. 62).

${ }^{49}$ Sewell Stokes, Pilloried! (London: Richards Press, 1928), p. 16, p. 37, p. 42, p. 32.

50 'We Nominate for the Hall of Fame', Vanity Fair, March 1924, p. 63.

${ }^{51}$ Advertisement, Vanity Fair, September 1918, p. 9.

${ }^{52}$ Stokes, p. 34, pp. 38-39.

${ }^{53}$ Present Indicative, p. 254, pp. 253-54.

${ }^{54}$ Shawna Ross, 'History, Mystery, Leisure, Pleasure': Evelyn Waugh, Bruno Latour, and the Ocean Liner', in Literary Cartographies: Spatiality, Representation, and Narrative, ed. by Robert T. Tally Jr. (New York: Palgrave, 2014), pp. 111-125 (p. 120).

${ }^{55}$ See West's Cousin Rosamund (published posthumously); also Coward's novella 'Bon Voyage' (1967), narrative poem 'P.\&O. 1930' (1957), and musical Sail Away (1961).

${ }^{56}$ Selected Letters of Rebecca West, ed. by Bonnie Kime Scott (New Haven: Yale University Press, 2000), p. 108.

${ }^{57}$ Vanity Fair, February 1926, p. 119.

${ }^{58}$ Letters of Noël Coward, p. 364

${ }^{59}$ Present Indicative, p. 271.

${ }^{60}$ Their relationship has barely been examined. Among the biographies, only Cole Lesley's makes more than a passing reference to West, devoting two pages to her visit to Coward in Switzerland. See The Life of Noel Coward (London: Jonathan Cape, 1976). Among literary 
critics, the only reference I have found is in MacKay, who briefly mentions their both being on the Gestapo's liquidation blacklist (pp. 57-58). 